\title{
The Role of Heparan Sulfate Proteoglycan in Ligand-induced Activation of the Epidermal Growth Factor Receptor
}

\author{
リガンドによって誘起される上皮細胞増殖因子レセプターの活性化における \\ ヘパラン硫酸プロテオグリカンの役割
}

\begin{abstract}
Johnson, Gibbes R.
Division of Cytokine Biology, Center for Biologics Evaluation and Research, Food and Drug Administration, Bethesda, MD 20892, USA, FAX: 1-301-402-1659
\end{abstract}

Key Words: amphiregulin, epidermal growth factor receptor, fibroblast growth factor, heparan sulfate proteoglycan, heparin-binding EGF-like growth factor

\begin{abstract}
The class of mammalian biologically active polypeptides called growth factors influence the proliferation, differentiation, motility, maintenance and apoptosis of target cells. Growth factors such as epidermal growth factor(EGF) and fibroblast growth factor (FGF) elicit responses in cells by interacting with the extracellular domain of their receptors. This binding results in the activation of the intrinsic tyrosine kinase activity of the receptor and signaling. It has become apparent that accessory receptors, namely heparan sulfate (HS) proteoglycan, are required for the action of some growth factors. The mechanism of action of the FGFs serves as the prototype for this phenomenon. Amphiregulin and heparin-binding EGF-like growth factor (HB-EGF), two ligands which function via the activation of the EGF receptor have been shown to require extracellular HS proteoglycan for bioactivity. The heparin-binding regions of amphiregulin and HB-EGF have been localized to a basic $\sim 20$ amino acid segment which lies just adjacent to the EGF-like domain of these mitogens. Based upon experimental data, a mechanism is proposed for amphiregulin action in which the HS proteoglycan is an integral membrane protein which either presents amphiregulin to the receptor or stabilizes the bivalent binding of one molecule of amphiregulin to the activated receptor dimer.
\end{abstract}

要 約

生物活性を持った哺乳類の成長因子と呼ばれるポリペプチ ドは、標的細胞の增殖、分化、移動、維持、アポトーシスに影 響を与えている。上皮細胞増殖因子(EGF)や繊維芽細胞増殖因子 (FGF)のような成長因子は、レセプターの細胞外ドメインと相互 作用することによって、細胞に反応を引き起こす。この結合の 結果、レセプター自身のチロシンキナーゼ活性とシグナル伝達 が活性化する。本来のレセプターに付随して存在する補助的レ セプターであるへパラン硫酸プロテオグリカンが、幾つかの成 長因子の作用に必要であることが明らかとなっている。FGFsの 機能発現の機構は、この現象のよいモデルである。EGFレセプ ターの活性化に必要な2つのリガンドであるアンフィレグリンと ヘパリン 結合性 EGF 様成長因子(HB-EGF)は、生物活性を発揮 するために、細胞外 HS プロテオグリカンを必要とすることが 示された。アンフィレグリンと HB-EGFのヘパリン結合領域 は、約20残基のアミノ酸配列からなる塩基性のペプチド断片に あることが示されており、それは分裂促進因子上の EGF 様ドメ インに非常に近接した位置に存在する。HS プロテオグリカンは アンフィレグリンの機能発現において必須の膜タンパク質であ り、アンフィレグリンをレセプターに提示したり、あるいは、 活性化されて二量体を形成したレセプターと一分子のアンフィ レグリンの二価の結合を安定化するといったメカニズムが、 データに基づいて提唱されている。

\section{A. Glycosaminoglycans and Proteoglycans}

Glycosaminoglycans (GAGs) are long unbranched polysaccharide chains consisting of repeating disaccharide units which can range in size from approximately 4,000 to $80,000,000$ daltons. GAGs can be classified into four groups based upon their sugar residues, the type of linkage between the sugar residues and the position and number of sulfate moities. The four main classes of GAGs are: (a) hyaluronic acid, (b) chondroitin sulfate and dermatan sulfate, (c) heparan sulfate and heparin, and (d) keratan sulfate. With the exception of hy-
A. グリコサミノグリカンとプロテオグリカン

グリコサミノグリカン $(\mathrm{GAG})$ は、長く、枝分かれのない多 糖鎖であり、約 4,000 80,000,000 ダルトンの二糖繰り返し領域 からなっている。GAGs は、その糖残基、糖残基間の結合様 式、硫酸基の位置と数の違いにより、4つのグループに分類され ている。GAGsの主要な4つのグループは、(a)ヒアルロン酸、(b) コンドロイチン硫酸とデルマタン硫酸、(c)へパラン硫酸とへパ リン、(d)ケラタン硫酸である。ヒアルロン酸を除いて、すべて の GAGs は様々に硫酸化されており、硫酸基は GAGs に強い負 
aluronic acid, all GAGs are sulfated to varying degrees which provides these GAGs with a strong negative charge. Heparan sulfate (HS) and heparin, which are the focus of this review, are composed of characteristic repeating glucuronic acid- $N$ acetylglucosamine disaccharide units. A number of additional modifications occur in HS and heparin including epimerization of glucuronic acid to iduronic acid and sulfation of the iduronic and glucosamine residues. Heparin differs from HS in that it contains a much higher degree of sulfation and quantity of iduronic acid. A more complete review on the structure, biosynthesis and metabolism of HS and heparin can be found in the review by Yanagishita and Hascall (1).

Proteoglycans are proteins which contain covalently linked GAGs and exist on the surface of cells and within the extracellular matrix. In contrast to the other GAGs, hyaluronic acid is not bound to a core protein and exists in a free form. Proteoglycans are believed to play an important role in a wide range of biological functions which include cell division, morphogenesis, developmental processes and cancer (1-5). One very important subset of proteoglycans is the HS proteoglycan which can exist on the surface of cells or within basement membranes (1,6-8). HS proteoglycan can exist on the surface of cells as integral membrane proteins, can be linked covalently to the cell surface via a glycosyl phosphatidylinositol (PI) anchor or can be bound to the surface through noncovalent specific or non-specific interactions with other plasma membrane proteins. The syndecan family of HS proteoglycans represent examples of integral membrane HS proteoglycans, whereas the glypican-related HS proteoglycans represent examples of PI-anchored HS proteoglycans $(1,7,8)$. HS proteoglycan can be expressed on the surface of cells at relatively high concentrations and typically can exist in the range of $10^{5}-10^{6}$ molecules/cell (1). Their ability to bind growth factors, enzymes, basement membrane proteins, proteinase inhibitors, and cytokines implies that HS proteoglycans perform very diverse biological functions. HS has been shown to play an essential role in the action of fibroblast growth factor (FGF) (9), vascular endothelial growth factor (VEGF) (10), amphiregulin (11), and heparin-binding EGF-like growth factor (HB-EGF) (12). While this review focuses on the binding of growth factors to the HS chains of proteoglycans, it is important to note that proteoglycans can also bind growth factors through their core proteins (2). For example, the proteoglycan, betaglycan, binds transforming growth factor- $\beta$ (TGF- $\beta$ ) through its protein core, and functions to present TGF- $\beta$ to the signal-transducing TGF- $\beta$ type II receptor (13).

\section{B. Signaling by Growth Factor Receptors Which Have In- trinsic Tyrosine Kinase Activity}

The class of polypeptide molecules called growth factors induce a number of biological responses in target cells.
の電荷を与えている。この総説の焦点であるへパラン硫酸(HS) とへパリンは、グルクロン酸とN-アセチルグルコサミンの特徽 的な二糖の繰り返しにより構成されている。HSとへパリンにお いては、グルクロン酸からイズロン酸へのエピメリ化と、イズ ロン酸残基とグルコサミン残基の硫酸化などの様々な修飾がみ られる。ヘパリンは、より硫酸化の程度が高く、イズロン酸の 含量が高いという点で HS とは異なる。HS および、ヘパリンの 構造、機能、生合成、代謝についての詳細はYanagishita と Hascall による総説に記載されている(1)。

プロテオグリカンは GAGs が共有結合している蛋白質であ り、細胞表面や細胞外マトリクス中に存在している。他の GAGs とは対照的に、ヒアルロン酸はコア蛋白質に結合してお らず、遊離した状態で存在する。プロテオグリカンは細胞分 裂、形態形成、個体の発生の過程、癌化を含む生物学的な機能 に、広範囲にわたって重要な役割を果たしていると信じられて いる(1-5)。プロテオグリカンの重要な亜群の1つとして、細胞 の表面や基底膜中に存在しているHS プロテオグリカンがある。 HS プロテオグリカンは、必須の膜蛋白質として細胞表面上に存 在していたり、グリコシルホスファチジルイノシトール(PI)アン カーを介して細胞表面に共有結合していたり、あるいは、非共 有結合的に他の形質膜蛋白質と特異的に、または、非特異的に 相互作用して、細胞表面に結合している。シンデカンファミ リーの HS プロテオグリカンは必須の膜結合型プロテオグリカ ンであり、グリピカン関連の HS プロテオグリカンはPIアン カーHS プロテオグリカンである(1、7、8)。HS プロテオグリ カンは、細胞表面に比較的高濃度に発現しており、典型的には $10^{5}-10^{6}$ 分子/細胞の範囲で存在している(1)。HS プロテオグリ カンが、種々の成長因子、酵素、基底膜中の蛋白質、プロテ アーゼインヒビター、サイトカインと結合することは、それら が非常に多彩な生物学的機能を発揮することを暗示している。 HS が繊維芽細胞增殖因子 $(F G F)(9)$ 、血管内皮細胞増殖因子

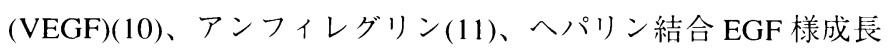
因子(HB-EGF)(12)の作用において、必須の役割を担っているこ とが示されている。この総説の焦点は、プロテオグリカン中の HS 鎖と種々の成長因子との結合であるが、プロテオグリカン は、そのコア蛋白質に打いても成長因子と結合することを記し ておくことも重要である(2)。例えば、ベータグリカンというプ ロテオグリカンは、そのコア蛋白質部分で、トランスフォーミ ング増殖因子- $\beta$ (TGF- $\beta$ ) と結合し、シグナルを変換する TGF- $\beta$ II レセプターにTGF- $\beta$ を提示するというように機能している(13)。

B. チロシンキナーゼ活性をもった成長因子レセプターによる シグナル伝達

成長因子と呼ばれるポリペプチドのクラスは、標的細胞に 数多くの生物学的な反応を引き起こす。これらの中には、細胞 
These responses include influencing the proliferation, differentiation, migration, maintenance and apoptosis of cells. Growth factors such as epidermal growth factor (EGF), insulin, FGF, nerve growth factor (NGF) and platelet-derived growth factor (PDGF) initiate their action through binding to the extracellular domain of their respective cell surface receptors. It is generally believed that ligand binding to these receptor leads to receptor dimerization, activation of the intrinsic tyrosine kinase activity of the receptor, autophosphorylation of the receptor and the generation of signals which eventually reach the nucleus (1416). The activation of signaling by the insulin receptor appears to be slightly different in the sense that the receptor pre-exists as a disulfide-linked dimer. While all of the specific steps and mechanisms involved in growth factor receptor signaling have not been elucidated, a general scheme appears to have emerged which can link these receptors to the nucleus of cells. Liganddependent signaling by these receptor tyrosine kinases results in the activation of the GTP-binding protein, Ras, which resides at the cytosolic side of the plasma membrane (17). The binding of a pre-existing complex of the adaptor protein, GRB2, and the guanine nucleotide exchange factor, son-of-sevenless (Sos), to tyrosine phosphorylated sites in the receptors themselves, as well as in other signaling proteins, drives the activation of Ras. The GRB2 protein is able to link itself to tyrosine phosphorylated sites and proline-rich sites in signaling proteins through its src homology 2 (SH2) and src homology 3 (SH3) domains, respectively. The activation of Ras initiates a phosphorylation cascade involving Raf kinase, mitogen-activated protein kinase kinase (map kinase kinase, MAPKK or MEK) and mitogen-activated protein kinase (map kinase, MAPK or extracellular signal-regulated kinase). The increase in the serine/threonine kinase activity of mitogen-activated protein kinase is believed to be essential for most, if not all, of the cellular response to growth factors (18-20). Recently, another pathway which links growth factor receptor signaling to the initiation of transcription within the nucleus has been discovered and appears to occur independent of Ras activation (21). Upon binding of ligand to receptor, a rapid tyrosine phosphorylation of signaling proteins called STATs (signal tranducers and stimulators of transcription) occur resulting in the translocation of the STAT proteins into the nucleus. It appears that this phenomenon is involved in the initiation of the transcription of early response genes. However, in terms of growth factor action, the biological consequence of the activation of this pathway is unknown.

\section{The Mechanism of FGF-Triggered Activation of the FGF Receptor as a Model for Heparan Sulfate-dependent Growth Factor Action}

Fibroblast growth factors comprise a large family of growth factors which play important roles in cell division, differentiation and embryogenesis $(22,23)$. While there are at
增殖、分化、移動、維持、アポトーシスへの影響が含まれる。 上皮細胞増殖因子(EGF)、インスリン、神経成長因子(NGF)、血 小板由来成長因子(PDGF)のような成長因子が、細胞表面に存在 する各々のレセプターの細胞外ドメインと結合することで、こ のような作用が始まる。一般的に、リガンドがレセプターと結 合すると、レセプターの二量体化、レセプター自身のチロシン キナーゼの活性化、レセプターの自己リン酸化が起こり、その ようにして生み出されたシグナルは、最終的に核へ到達する (14-16)。インスリンレセプターによりシグナル伝達が活性化さ れる場合は、レセプターがジスルフィド結合によりあらかじめ 二量体として存在しているので、その点が、多少異なるよう だ。成長因子のシグナル伝達に関与する特異な過程や機構のす べてが解明されたわけではないが、細胞のこれらのレセプター と核をつなぐ概要は明らかになったように思える。これらのレ セプターチロシンキナーゼによる、リガンドに依存したシグナ ル伝達の結果、形質膜の細胞質側に存在する GTP 結合蛋白質で あるRas タンパクの活性化が起こる(17)。アダプター蛋白質であ るGRB2 とグアニジンヌクレオチド変換因子であるson-ofsevenless(Sos)の既存の複合体がレセプター自身のリン酸化チロ シン残基へ結合することも、他のシグナル蛋白質の場合と同様 にRasの活性化を引き起こす。GRB2 蛋白質はそれ自身が、その src homology 2(SH2)やsrc homology 3(SH3) ドメインを介して、シ グナル蛋白質中のリン酸化を受けたチロシン残基やプロリン リッチな部位とそれぞれ結合することができる。Rasの活性化 により、Raf キナーゼ、MAPキナーゼキナーゼ(map kinase kinase、MAPKK、MEK)、MAPキナーゼ(map kinase 、MAPK、 extracellular signal-regulated kinase)の関与するリン酸化のカス ケード反応が起こる。セリン/スレオニン/チロシンキナーゼのセ リン/スレオニンキナーゼ活性の上昇が、成長因子の細胞応答反 応の寸べてとはいわないまでも、大部分において重要であると 考えられている(18-20)。最近、成長因子とそのレセプターを介 したシグナリングと核内での転写の開始をつなぐ他の経路が発 見され、それはRasの活性化には依存しないようである(21)。 リガンドとレセプターとの結合によって、STATs(signal transducers and stimulators of transcription) と呼ばれるシグナル伝達蛋 白質のチロシン残基の迅速なりン酸化が起こり、その結果、 STAT 蛋白質は核へ移行する。この現象は、初期応答する遺伝 子の転写の開始に関係すると考えられる。しかしながら、成長 因子の作用という観点においては、この経路の活性化の結果、 どのような生物学的反応が生じるのかはわかっていない。

C. ヘパラン硫酸に依存した成長因子の作用のモデルとして の、FGFにより引き起こされる FGFレセプターの活性化のメ カニズム

繊維芽細胞増殖因子は、細胞の分裂、分化、胚発生におい て重要な役割を果している成長因子の巨大ファミリーを形成し ている(22、23)。このファミリーのなかには、少なくとも9種の 
least nine different FGFs within this family, the following discussion will focus on the most studied members of this family, namely acidic FGF (aFGF, FGF-1) and basic FGF (bFGF, FGF-2). The FGFs are potent stimulators of endothelial cell mitogenesis and angiogenesis. Over the last several years significant progress has been made in understanding the role that HS and HS proteoglycan play in FGF action and thus, provide us with a prototypical mechanism for HS-dependent growth factor action. It has been well recognized that heparin can potentiate the bioactivity of the FGFs and cells which lack HS proteoglycan, do not respond to $\operatorname{bFGF}(9,24,25)$. However, the action of bFGF can be reconstituted in these cells by adding soluble heparin or heparan sulfate in the presence of bFGF. It has been proposed that cell-surface, heparin-like molecules (HS) are necessary for binding of bFGF to its high affinity, signal-transducing tyrosine kinase receptor (25). In contrast to these findings, Roghani et al. (26) have provided data which indicates that heparin is not essential to bFGF binding to its receptor, but instead increases the affinity of the interaction in the $\mathrm{bFGF/receptor} \mathrm{complex.} \mathrm{It} \mathrm{also} \mathrm{has} \mathrm{been} \mathrm{demonstrated} \mathrm{that}$ heparin binds to the FGF receptor and proposed that this interaction is essential to the aFGF and bFGF activity (27). Numerous studies have identified structures in heparin and heparan sulfate which are critical to the bioactivity of bFGF and aFGF (28-33). Oligosaccharides rich in 2- $O$-sulfo- $\alpha$-L-iduronic acid and containing at least 10 sugar units were found to bind strongly to the FGFs and to confer biological activity to the FGFs. Interestingly, these highly negative charged structures are common to heparin, but rare in HS. The work of Aviezer $e t$ $a l$. has demonstrated that the cell surface HS proteoglycans, syndecan, glypican and fibroglycan are not able to drive high affinity binding of bFGF to its receptor (32). However, a very recent report from this group indicates that the basal lamina HS proteoglycan, perlecan, promotes bFGF-mediated mitogenesis and angiogenesis (34). A specific mechanism which may explain the role of heparin and HS in aFGF action has recently been put forth (35). It has been proposed that heparin functions to induce oligomerization of aFGF molecules and that this oligomerization of growth factor molecules is responsible for FGF receptor dimerization, activation and mitogenesis.

\section{Multiple Ligands Activate the Epidermal Growth Factor Receptor}

The activated EGF receptor mediates a number of important biological responses in mammals including the stimulation of cell division, migration, and differentiation (36). Five different polypeptide ligands which derive from distinct genes are capable of binding to the extracellular domain of the EGF receptor and thus, inducing the generation of an activated, signaling receptor. These ligands include $\operatorname{EGF}(36,37)$, transforming growth factor- $\alpha$ (TGF- $\alpha)(38,39)$, amphiregulin (40-45),
異なった FGFが存在するが、以下の議論では、このファミリー のうち、最もよく研究された成長因子である acidic FGF (aFGF、 FGF-1) と basic FGF(b FGF、FGF-2)に焦点を絞る。FGFs は内皮 細胞の細胞分裂や血管新生の強力な刺激因子である。過去数年 間にわたって、FGFの作用において HS と HS プロテオグリカ ンの果たす役割の理解における相当な研究の進歩があり、その ようにして我々は、HS に依存した成長因子の作用の機構の原型 を知るようになった。へパリンが FGFs の生物活性を高めるこ とや、HS プロテオグリカンを欠如した細胞はbFGFに応答し ないことはよく知られている(9、24、25)。しかし、可溶性のへ パリンやヘパラン硫酸をbFGF 存在下に添加すると、これらの細 胞に㧈いて bFGF の作用を構築することができる。細胞表面上 のへパリン様分子(HS)が、bFGF の高親和性レセプターである シグナル伝達チロシンキナーゼレセプターとの結合に必要であ ることが提唱されている(25)。これらの知見とは対照的に、

Roghaniらは(26)、ヘパリンは bFGFとそのレセプターの結合 には必須ではないが、その代わりに、bFGF/レセプター複合体 における相互作用の親和力を増すというデー夕を提出した。へ パリンはFGFレセプターと結合することも示され、この相互作 用が $\mathrm{aFGF}$ と $\mathrm{bFGF}$ の活性にとって必須であることが提言され た(27)。多くの研究により、b FGF と aFGF の生物活性にとって 決定的なへパリンとへパラン硫酸中の構造が同定された $(28-$ 33)。2位が硫酸化された $\alpha$-L-イズロン酸に富んだ、少なくとも 10 糖単位を含んでいるオリゴ糖が、FGFs と強く結合すること や、FGFs に生物活性を与えることが観察された。興味深いこと に、これらの非常に負に荷電した構造はへパリンに扔いて一般 的であるが、HSにとっては稀である。Aviezerらの研究は、細 胞表面の HS プロテオグリカンであるシンデカン、グリピカン、 フィブログリカンは、bFGFをそのレセプターに非常に強く結合 させることはできないことを示している(32)。しかしながら、 このグループの最近の報告は、基底層の HS プロテオグリカン であるパールカンは、bFGFが媒介する細胞分裂や血管新生を 促進することを示している(34)。a FGF の作用におけるへパリン と HS の役割を説明する特異的な機構が、最近、提出された (35)。ヘパリンはa FGF 分子のオリゴマー化を引き起こすという 機能を果たし、また、このような成長因子分子のオリゴマー化 がFGFレセプターの二量体化、活性化、細胞の分裂促進の原因 となっていることが提唱されている。

\section{D. 多数のリガンドが上皮細胞増殖因子レセプターを活性化す る}

活性化した EGFレセプターは、ほ乳類に扔いて、細胞の 分裂、移動、分化の刺激を含む多くの重要な生物学的反応を媒 介している(36)。異なった遺伝子の産物である五種のポリペプ チドリガンドは、EGFレセプターの細胞外ドメインに結合で き、そ机ゆえ、活性化さ机たシグナルレセプターを誘導でき

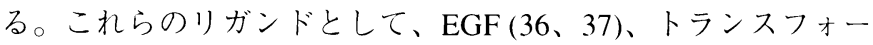

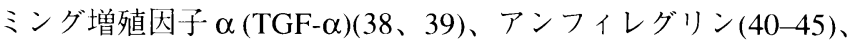


$\operatorname{HB}-\operatorname{EGF}(12,46,47)$ and betacellulin $(48,49)$. Amphiregulin, HB-EGF and betacellulin have all been shown to bind to immobilized heparin, in contrast to EGF and TGF- $\alpha$ which do not. Relative to amphiregulin and HB-EGF, betacellulin binds weakly to heparin (49). All of these growth factors contain a characteristic EGF-like domain which is defined by 6 evenly spaced cysteines residues which generate 3 loops through the formation of disulfide bonds. In the case of amphiregulin and HB-EGF, these growth factors contain a very basic $\mathrm{NH}_{2}$-terminal extension of varying length relative to the EGF-like domain. All of these EGF-like polypeptides are believed to be released from cells via proteolytic processing of their transmembrane precursors. However, some evidence exists that these growth factors are biologically active in their cell-anchored transmembrane forms $(39,50)$. In addition to the aforementioned polypeptide mitogens, another heparin-binding growth factor which acts through the EGF receptor has been discovered, called schwannoma-derived growth factor (51), and is believed to be the rat homolog of human amphiregulin.

\section{E. Heparan Sulfate is Necessary for Amphiregulin- and HB-EGF-Induced Signaling by the Epidermal Growth Fac- tor Receptor}

Relatively high concentrations of soluble heparin have been demonstrated to inhibit the mitogenic activity of amphiregulin $(11,42)$ and to inhibit the binding of HB-EGF to the EGF receptor (47). This phenomenon appears to be somewhat specific since chondroitin sulfate was only slightly inhibitory $(11,47)$. Conversely, the bioactivity of betacellulin is not affected by soluble heparin (49). Since growth factors are unlikely to ever encounter the highly negatively charged GAG, heparin, in vivo (2), it was not initially clear whether the inhibition of amphiregulin and HB-EGF action by heparin was of any physiological significance. In this regard it is worth noting that soluble HS was as equally effective as heparin at inhibiting amphiregulin-induced cell growth (11). To test the hypothesis that amphiregulin and HB-EGF utilized the heparin-related GAG, HS, to activate the EGF receptor, a number of approaches were used. Treatment of cells with chlorate, an inhibitor of ATP-sulfurylase, blocks sulfation of GAGs (24). The ability of amphiregulin to trigger autophosphorylation of the EGF receptor and to induce mitogenesis is blocked by chlorate treatment of MCF-10A human mammary epithelial cells (11). Most importantly, these responses to amphiregulin are rescued by adding $5 \mathrm{mM}$ sodium sulfate to the culture medium confirming that chlorate functions specifically to inhibit sulfation. Chlorate treatment of bovine aortic smooth muscle cells (BASMCs) and chinese hamster ovary ( $\mathrm{CHO}$ ) cells inhibits HB-EGF-evoked BASMC migration and binding of radiolabeled HB-EGF to EGFR-devoid CHO cells (12). Exposure of cells to the GAG-degrading enzymes heparinase (EC 4.2.2.7)
HB-EGF(12、46、47)、ベータセルリン $(48 、 49)$ がある。アン フィレグリン、HB-EGF、ベータセルリンは、固相化されたへ パリンに結合するが、EGF とTGF- $\alpha$ は結合しないことが示され ている。アンフィレグリン、HB-EGF と比較すると、ベータセ ルリンのへパリンへの結合は弱い(49)。これらの成長因子のす べてが、特徽的な EGF 様ドメインを含んでおり、それは、等間 隔に存在している6つのシステイン残基によりジスルフィド結合 が形成され、それによって3つのループが生じている。アンフィ レグリンと HB-EGFの場合は、これらのすべての成長因子は、 EGF 様ドメインと比べると、長さの異なる非常に塩基性のN末 端伸長配列を持っている。これらのすべての EGF様ポリペプチ ドは、膜を貫通した前駆体がタンパク分解酵素によるプロセッ シングをうけて、細胞より遊離すると考えられている。しか し、成長因子は、膜を貫通して細胞に結合した型で生物学的に 活性であるという証拠もある(39、50)。さらに、前述のポリペ プチドの分裂促進因子の他にもう1つ、EGFレセプターを通して 作用する、シュワン細胞腫由来成長因子(51)と呼ばれているへ パリン結合成長因子が見つけられ、ラットのそれはヒトのアン フィレグリンのホモローグであると考えられている。

E. ヘパラン硫酸は、アンフィレグリンと HB-EGF が誘導する、 上皮細胞增殖因子(EGF)レセプターによるシグナル伝達に必要 である

比較的高濃度の可溶性のへパリンはアンフィレグリンの分 裂促進活性(42)、および、HB-EGF と EGFレセプターの結合を 阻害することが示されている(47)。コンドロイチン硫酸ではわ ずかに阻害がかかるにすぎないので(11、47)、この現象は幾分 特異的であるようだ。逆に、ベータセルリンの生物活性は可溶 性のへパリンによって影響を受けない(49)。成長因子は、in vivo では、高度に負に荷電したGAGであるへパリンと接触しそう にないので(2)、ヘパリンによるアンフィレグリンやHB-EGF の 作用の阻害が、生理的に意義があるかどうかははじめは不明で あった。この点に関して、アンフィレグリンにより誘導される 細胞成長を阻害するのに、可溶性の HS が可溶性のヘパリンに 匹敵するほど有効であるということは特に指摘する価值がある (11)。アンフィレグリンと HB-EGFがEGF レセプターを活性化 するために、へパリン関連 GAG であるHS が必要であるという 仮説を検証するため、数多くのアプローチがなされた。ATP-ス ルフリラーゼのインヒビターである塩素酸塩で細胞を処理する と、GAGs の硫酸化が阻害される(24)。EGFレセプターの自己 リン酸化を引き起こし細胞分裂を誘導するアンフィレグリンの 活性は、ヒ卜乳腺上皮細胞である MCF-10A の塩素酸処理によ り阻止される(11)。非常に重要なのは、これらのアンフィレグ リンに対する反応性が $5 \mathrm{mM}$ 硫酸ナトリウムを培養培地に添加 することによって回復することであり、塩素酸が硫酸化を特異 的に阻害していることが確認できる。ウシ大動脈平滑筋細胞 (BASMCs) とチャイニーズハムスター卵巣 $(\mathrm{CHO})$ 細胞を塩素酸で 処理すると、HB-EGFにより引き起こされるBASMCの移動や、 アイソトープ標識HB-EGF のEGFレセプター 欠損 CHO 細胞へ の結合が阻害される(12)。細胞を GAG 分解酵素であるへパリ ナーゼ(EC 4.2.2.7)やへパリチナーゼ(EC 4.2.2.8)に曝すと、細胞 
or heparitinase (EC 4.2.2.8) cleave distinct sites within cell surface HS chains (52). Digestion of HS chains with either of these enzymes inhibits AR-induced activation of the EGF receptor and mitogenesis, but has no effect on EGF-dependent responses (11). Binding of ${ }^{125}$ I-HB-EGF to the EGF receptor and HB-EGF stimulation of BASMC motility are also inhibited by treatment of cells with heparinase $(12,47)$. Additionally, binding of radiolabeled HB-EGF to mutant $\mathrm{CHO}$ cells deficient in HS production is significantly reduced relative to wild type CHO cells (12). HS proteoglycan is necessary for amphiregulin- and HB-EGF-triggered autophosphorylation of tyrosine residues in the $\mathrm{COOH}$-terminal tail of the EGF receptor (11, 53). Taken together, these data demonstrate that amphiregulin and $\mathrm{HB}-\mathrm{EGF}$ require extracellular $\mathrm{HS}$ proteoglycan for EGF receptor binding and signal transduction. The data does not rule out the possibility that the requisite HS proteoglycan(s) may also exist and function within extracellular matrix which is synthesized by the cells. It is not clear whether amphiregulin and HB-EGF utilize a common HS proteoglycan to activate the EGF receptor. Further, AR and HB-EGF may exploit distinct structures within certain HS chains for their bioactivity. Preliminary experiments studying the mitogenic response of MCF-10A cells to amphiregulin and HB-EGF indicated that amphiregulin was significantly more potent suggesting that these two activators of the EGF receptor may necessitate discrete HS proteoglycans or HS structures for function (G. R. Johnson, unpublished observations). Consistent with this view is the finding that HS-containing CD44 isoforms are able to bind HB-EGF, but do not bind amphiregulin (54).

\section{F. Regions in Amphiregulin and HB-EGF that Are In- volved in the Interaction with Heparin}

In contrast to EGF and TGF- $\alpha$, amphiregulin, HB-EGF and betacellulin contain an $\mathrm{NH}_{2}$-terminal extension relative to their EGF-like domain. In the case of betacellulin, which binds weakly to heparin and whose bioactivity is not inhibited by heparin, this region is not essential for bioactivity nor for heparin binding (49). However, this $\mathrm{NH}_{2}$-terminal extension appears to be critical to the ability of amphiregulin and HB-EGF to activate the EGF receptor and induce responses in target cells. As seen in Fig. 1, this region of amphiregulin and HB-EGF is rich in lysine and arginine residues. Previous work from my laboratory has demonstrated that residues 26-44 of amphiregulin (underlined in Fig. 1) bind to heparin and can block the ability of amphiregulin to interact with immobilized heparin (11). Since HS is just as effective as heparin at inhibiting amphiregulinevoked mitogenesis (11), it is very likely that residues $26-44$ of AR bind to HS in an analogous manner. Similar studies using synthetic peptides and recombinant mutant forms of HB-EGF indicated that a region of 21 amino acids running from residues 21-41 of HB-EGF (underlined, Fig. 1) is responsible for the
表面の HS 鎖内の異なる部位が切断される(52)。どちらかの酵素 でHS 鎖を消化すると、アンフィレグリンに誘導された EGFレ セプターの活性化と細胞分裂が阻害されるが、EGFに依存した 反応には影響を与えない(11)。EGF レセプターへの ${ }^{125}$ I-HB-EGF の結合と、HB-EGFにより刺激されて起こるBASMC の移動も また、細胞のへパリナーゼ処理により阻害される(12、47)。加 えて、アイソトープで標識された HB-EGFの HS 産生能の欠損 した変異株 $\mathrm{CHO}$ 細胞への結合は、野生型 $\mathrm{CHO}$ 細胞に比べて有 意に低下している(12)。HS プロテオグリカンは、EGFレセプ ターのC 末端に存在するチロシン残基の、アンフィレグリンと HB-EGFに引き起こされる自己りン酸化反応に必要である(11、 53)。総合して、これらの結果は、アンフィレグリンと HB-EGF が、EGFレセプターと結合してシグナルを伝達するために、細 胞外 HS プロテオグリカンが必要であるということを示してい る。これらの結果は、細胞により合成される細胞外マトリクス 内に活性に必須の HS プロテオグリカンが存在し機能している という可能性を否定することはできない。アンフィレグリンと HB-EGFがEGFレセプターを活性化するために共通の HS プロ テオグリカンを要求するかどうかは不明である。さらに、アン フィレグリンと HB-EGFはそれらの生物活性を発揮するため に、ある一定の HS 鎖中の異なった構造を利用しているのかも しれない。MCF-10A 細胞のアンフィレグリンと HB-EGFに対 するマイトジェニックな反応を調べる予備的な実験は、アン フィレグリンの方がより強力であることを示しており、そのこ とはEGFレセプターのこれら2つのアクチベーターが機能する ためには、別々の HS プロテオグリカン、あるいは別々の HS の 構造を必要としているかもしれないことを示唆している(G. R. Johnson, 未発表)。この見解は、HS を含むCD44のアイソフォー ムが、HB-EGF とは結合できるがアンフィレグリンとは結合し ないという知見とも一致している(54)。

F. ヘパリンと相互作用に関与するアンフィレグリンと HBEGF 中の領域

EGF、TGF- $\alpha$ と比較して、アンフィレグリン、HB-EGF、 ベータセルリンは、EGF様ドメインの $\mathrm{N}$ 末端側に伸長配列を含 んでいる。ヘパリンと弱く結合し、その生理活性がへパリンで 阻害されないべータセルリンの場合は、この領域は生物活性 や、ヘパリンとの結合に必須ではない(49)。しかしながら、N末 端に存在する伸長配列は、アンフィレグリンや、HB-EGF が EGFレセプターを活性化し、標的細胞に応答を引き起こすのに 非常に重要である。図1のように、アンフィレグリンと HB-EGF 中のこの領域には、リジンとアルギニン残基が多く含まれてい る。

著者の研究室の以前の研究は、アンフィレグリン由来(Fig. 1の下線部)の 26-44 番目の残基(図1の下線部)がへパリンと結合 し、アンフィレグリンと固相化したへパリンとの相互作用を阻 害できることを示した(11)。HS はへパリン同様、アンフィレグ リンにより引き起こされた細胞分裂を阻害するのに有効である ので(11)、アンフィレグリンの 26-44 番目残基と HS はよく似 た様式で結合する可能性が大である。合成ペプチドとリコンビ ナントの変異体 HB-EGF を用いた同様の研究で、HB-EGF の 21-41 番目の 21 アミノ酸残基からなる領域(図1の下線部)が、 


\section{A.

\author{
$* * * * * * \quad * \quad * * \downarrow$ \\ AR (19-54): ...NTSDKPKRKKKGGKNGKNRRNRKKKNPCNAEFQNFC... \\ HB-EGF (15-44): ...NKEEHGKRKKKGKGLG----------KKRDPCLRKYKDFC...
}

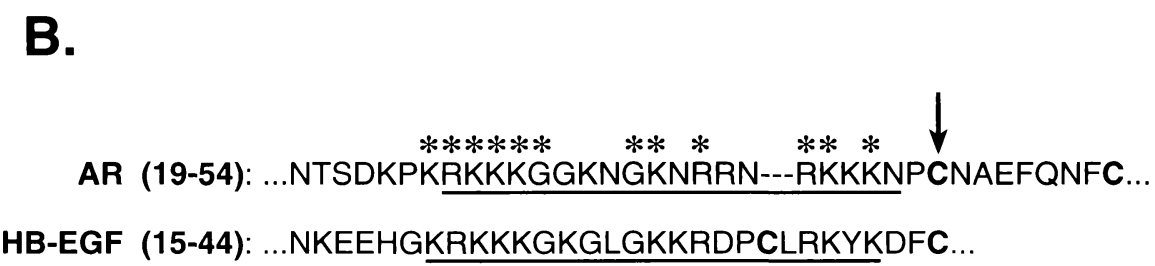

Fig. 1. Alignment of the heparin-binding domains of amphiregulin and HB-EGF. Two distinct alignments of the amino acid sequences of the heparin-binding regions of amphiregulin (AR) and HB-EGF are presented. The numbers in parentheses correspond to the amino acid residues within the mature proteins. The underlined sequences represent regions which have been demonstrated to directly interact with heparin or heparan sulfate. The asterisks denote positions where amino acid residues are identical when the sequences are aligned. In A, the sequences have been aligned relative to the first cysteine contained within the EGF-like domain of both proteins. This first cysteine is denoted by the arrow. In B, the sequences have been aligned relative to the first cysteine in $A R$ and the second cysteine in HB-EGF (denoted by arrow) as proposed by Thompson et al. (55).

ability of HB-EGF to bind heparin $(12,47,55)$. Furthermore, a synthetic peptide corresponding to this region of HB-EGF inhibits the response of target cells to HB-EGF suggesting that this region binds to cell surface HS also (12). Interestingly, and unlike amphiregulin, the heparin-binding domain of HB-EGF runs past the first cysteine residue and into the EGF-like domain. Fig. 1 A depicts a comparison of the sequences of amphiregulin and HB-EGF when the two sequences are aligned relative to the first cysteine of the EGF-like domain of the two polypeptides. As seen in Fig. 1B, even greater homology can be observed when the sequences of the two heparin-binding domains are aligned relative to the first cysteine of amphiregulin and the second cysteine of HB-EGF (55). Within the heparinbinding domain of amphiregulin are two short sequences of Arg-Lys-Lys-Lys which have been proposed to function as nuclear localization signals. Immunoreactive amphiregulin has been detected by several different investigators within the nucleus of cells in vitro and in vivo $(43,56-61)$. Only one of these putative nuclear localization signals exists in HB-EGF (Fig. 1) and there is no published evidence that HB-EGF can be targeted to the nucleus of cells. The biological consequence of the nuclear accumulation of amphiregulin is unknown. Nevertheless, in an extracellular environment residues $26-44$ of amphiregulin functions as a heparan sulfate-binding site essential for activation of the EGF receptor, whereas within cells this region of amphiregulin may be critical to targeting to the nucleus.

Utilizing computer graphics techniques, a distinct spatial distribution of basic residues appears to be necessary for the ability of proteins to interact with heparin (62). In this model, two basic amino acid residues are located at about 20 angstroms
HB-EGF とへパリンの結合に不可欠であることが示された(12、 47、55)。さらに、HB-EGF 中のこの領域に相当する合成ペプチ ドは標的細胞の HB-EGFへの応答を阻害し、そのことは、この 領域が細胞表面の HS と結合することを示唆している(12)。興味 深いことに、アンフィレグリンとは異なり、HB-EGFのヘパリ ン結合ドメインは、最初のシステイン残基からEGF様ドメイン まで続いている。図1では、2つのポリペプチドの EGF様ドメイ ン中の最初のシステイン残基を基準にして並べて、アンフィレ グリンと HB-EGFの配列を比較している。Fig. 1Bで示すよう に、アンフィレグリンの最初のシステイン残基とHB-EGFの二 番目のシステイン残基を基準にして並べると、より高いホモロ ジーが観察される(55)。アンフィレグリンのヘパリン結合ドメ インには、核に局在するためのシグナルとして機能すると提唱 されている、Arg-Lys-Lys-Lys という2つの短いシークエンスが 存在する。免疫学的に活性なアンフィレグリンは、何人かの研 究者により、in vitro や in vivoにおいて、細胞の核に検出され ている(43、56-61)。EB-EGFには、これらの推定上の核に局在 するためのシグナルのうちのにつだけが存在しているが(図1)、 HB-EGFが核へ移行しうるという証拠は報告されていない。ア ンフィレグリンが核へ蓄積した結果おこる生物学的な現象は不 明である。しかしながら、アンフィレグリンの 26-44番目の残 基は、細胞外環境では、EGFレセプターの活性化に不可欠なへ パラン硫酸結合部位として機能し、一方細胞内においては、ア ンフィレグリンのこの領域は、核へのターゲッティングに決定 的な役割を果たすのかもしれない。

コンピューターグラフィックスの技術を利用して、タンパ ク質がヘパリンと相互作用するためには、塩基性アミノ酸の独 特な空間的配置が必要であることが明らかになった(62)。この モデルでは、2つの塩基性アミノ酸残基が $\alpha$ ヘリックスの真向か いに、約 20 オングストローム離れて位置しており、これら2つ 
apart facing opposite directions of an $\alpha$-helix with basic residues dispersed between these two residues. An amphipathic structure is generated with basic residues on one side of the helix and nonpolar residues on the other. A similar spatial arrangement is compatible with a $\beta$-sheet structure that binds heparin. Alignment of these linear sequences demonstrated that the $\alpha$-helix structures contain two basic residues separated by 12 amino acid residues, whereas the two basic residues are separated by 6 amino acid resiues in the $\beta$-sheet structures (62). This model appears to be consistent with the experimentally determined heparin-binding domains of amphiregulin and HBEGF.

\section{G. A Proposed Mechanism for the Role of HS Proteoglycan in Amphiregulin-Induced Activation of the EGF Receptor}

Much of our understanding of how HS proteoglycan can function as an accessory protein to facilitate the biological action of growth factors is derived from studies on the FGF family of growth factors. However, based upon the currently available data, there appears to be several differences between the mechanisms that FGF and amphiregulin utilize to activate their respective receptors. These differences are as follows: i) heparin/HS at the appropriate concentrations can act to potentiate the activity of FGF, whereas heparin/HS always functions as an inhibitor of amphiregulin bioactivity, presumably due to masking of the heparin-binding site in amphiregulin; ii) soluble heparin/HS can substitute for the presence of the HS proteoglycan and can reconstitute the biological action of FGF, but not that of amphiregulin, in cells which lack the requisite HS proteoglycan $(11,24)$; and iii) FGF is monovalent in the sense that each FGF molecule binds one receptor monomer in the activated signaling receptor dimer, whereas ligands for the EGF receptor are bivalent and a single molecule can bind simultaneously to two receptor molecules (63). Treatment of cells with PI-specific phospholipase $\mathrm{C}$ had no effect on amphiregulin-induced mitogenesis suggesting that the HS chains essential for amphiregulin function are not PI-anchored to the cell surface (11). Additionally, the HS chains do not appear to be conjugated to the EGF receptor itself (11). Thus, the HS proteoglycan is probably a cell surface integral membrane protein similar to the syndecan family of HS proteoglycans. Due to the fact that soluble heparin/HS cannot rescue the amphiregulin response in cells which are deficient in HS proteoglycan indicates that the HS chains need to be tethered to the surface of the cells. This situation is analogous to the role that betaglycan plays in presenting TGF- $\beta$ to the TGF- $\beta$ type II receptor in which betaglycan needs to be tethered to the cell surface for TGF- $\beta$ action (13). Amphiregulin can compete, albeit weakly, for the specific binding of radiolabeled EGF to immobilized plasma membrane preparations suggesting the possibility that some binding of AR may occur directly to the EGF receptor
の残基間に塩基性のアミノ酸が分散している。ヘリックスの 方側に存在する塩基性アミノ酸と他方側に存在する非極性のア ミノ酸残基によって、両親媒性の構造がつくりだされる。へパ リンに結合するべータシート構造においても、同様の空間的な

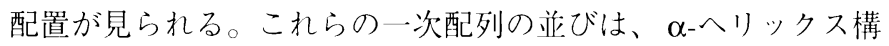
造は12のアミノ酸残基により隔てられた2つの塩基性アミノ酸 を含み、ベータシート構造では2つの塩基性アミノ酸残基が $6 つ$ のアミノ酸残基により隔てられていることを示している(62)。 このモデルが、アンフィレグリンと HB-EGFの実験的に決めら れたへパリン結合ドメインと一致していることが明らかとなっ ている

G. アンフィレグリンにより誘導されるEGFレセプターの活 性化における HS プロテオグリカンの役割のために提唱された 機構

成長因子の生物学的な作用を促進するために、HS プロテ オグリカンが補助タンパク質としてどのようにして機能するの かについての多くの知見は、成長因子の FGFファミリーの研究 より得られた。しかしながら、現在あるデータに基づくと、 FGF とアンフィレグリンが、それぞれのレセプターを活性化す るために使う機構の間には、いくらかの違いがあることが明ら かである。こ扎らの違いは以下のようである。i 適度な濃度の ヘパリン/HSは、FGFについては、活性を高めるように作用す るが、アンフィレグリンについては、おそらく、アンフィレグ リンのヘパリン結合領域をマスクすることにより、その生物活 性の阻害物質として機能する。ii)可溶性のへパリン/HS は HS プ ロテオグリカンの代用となり、必須である HS プロテオグリカ ンを欠いた細胞において、FGFの生物活性を構築できるが、ア ンフィレグリンの活性は構築できない(11、24)。iii)1つのFGF 分 子は、活性化された二量体において1つのレセプター単量体と結 合するので、FGFは一価といえるが、EGFレセプターのリガン ドは二価であり、一分子は同時に2つのレセプター分子に結合す る(63)。細胞をPI 特異的ホスフォリパーゼ Cで処理しても、ア ンフィレグリンにより誘尊される細胞分裂には影響を与えない ことより、アンフィレグリンの機能に必須の HS 鎖は、細胞表 面にPIアンカーによって結合していないことを示唆している (11)。さらに、EGFレセプター自身には結合していないことが 明らかになった(11)。それゆえ、HS プロテオグリカンは、拀そ らく、シンデカンファミリーの HS プロテオグリカンのような 細胞表面の必須の膜タンパク質である。可溶性のヘパリン $/ \mathrm{HS}$ により、HS プロテオグリカンを欠いた細胞におけるアンフィレ グリンの反応を回復できないということは、HS 鎖が細胞表面に 結合している必要があることを示している。これは、TGF- $\beta$ を TGF- $\beta$ タイプII レセプターに提示するベータグリカンの役割と 類似しており、TGF- $\beta$ の作用を発揮させるためには、ベータグ リカンは細胞表面に結合している必要がある(13)。アンフィレ グリンが、アイソトープで標識した EGF と固相化された形質膜 との特異的な結合と、弱いながらも競合できることは、アン フィレグリンのうちのある分子は、細胞表面に正しい力向に埋 
Fig. 2. A proposed mechanism for the role of HS proteoglycan in amphiregulin-triggered activation of the EGF receptor. The model represents a proposed mechanism for the cell surface activation of the EGF receptor by amphiregulin (AR) based upon the currently available data. HSPG represents an integral membrane heparan sulfate proteoglycan and TK represents the cytoplasmic tyrosine kinase domain of the EGF receptor. Depicted at the bottom of the figure is a complex of HSPG, AR and activated dimerized EGF receptor containing multiple autophosphorylated tyrosine residues $(\mathrm{P})$ within the $\mathrm{COOH}$-terminal tail of the receptor. The pathway depicted on the left is called the presentation mechanism, whereas the pathway depicted on the right is called the stabilization mechanism of amphiregulin action.

without the properly oriented cell surface HS chains (40). Based upon all of this information, a mechanism for the action of amphiregulin can be proposed (Fig. 2). Note that amphiregulin is depicted as a structure with a round compact EGF-like domain and an $\mathrm{NH}_{2}$-terminal extension containing the HS-binding region. Amphiregulin can initially bind to either the HS proteoglycan (HSPG) or to the ligand binding site of the EGF receptor. When amphiregulin binds first to HS proteoglycan, the HS chains can then present amphiregulin in the proper spatial orientation to the EGF receptor. Once amphiregulin has been presented to the receptor monomer, dimerization, autophosphorylation and activation of and signaling by the EGF receptor follows. This can be considered or called the presentation mechanism of amphiregulin action. When the amphiregulin molecule binds first to the ligand-binding site of the EGF receptor, the HS chains of the proteoglycan can bind to amphiregulin and stabilize the interaction between ligand and receptor at the cell surface. This also rapidly leads to activation and signaling by the EGF receptor. This pathway is called the stabilization mechanism of amphiregulin action. One potential difference between amphiregulin and HB-EGF is that in cells which are deficient in HS proteoglycan binding of HBEGF to the receptor can be reconstituted by soluble heparin

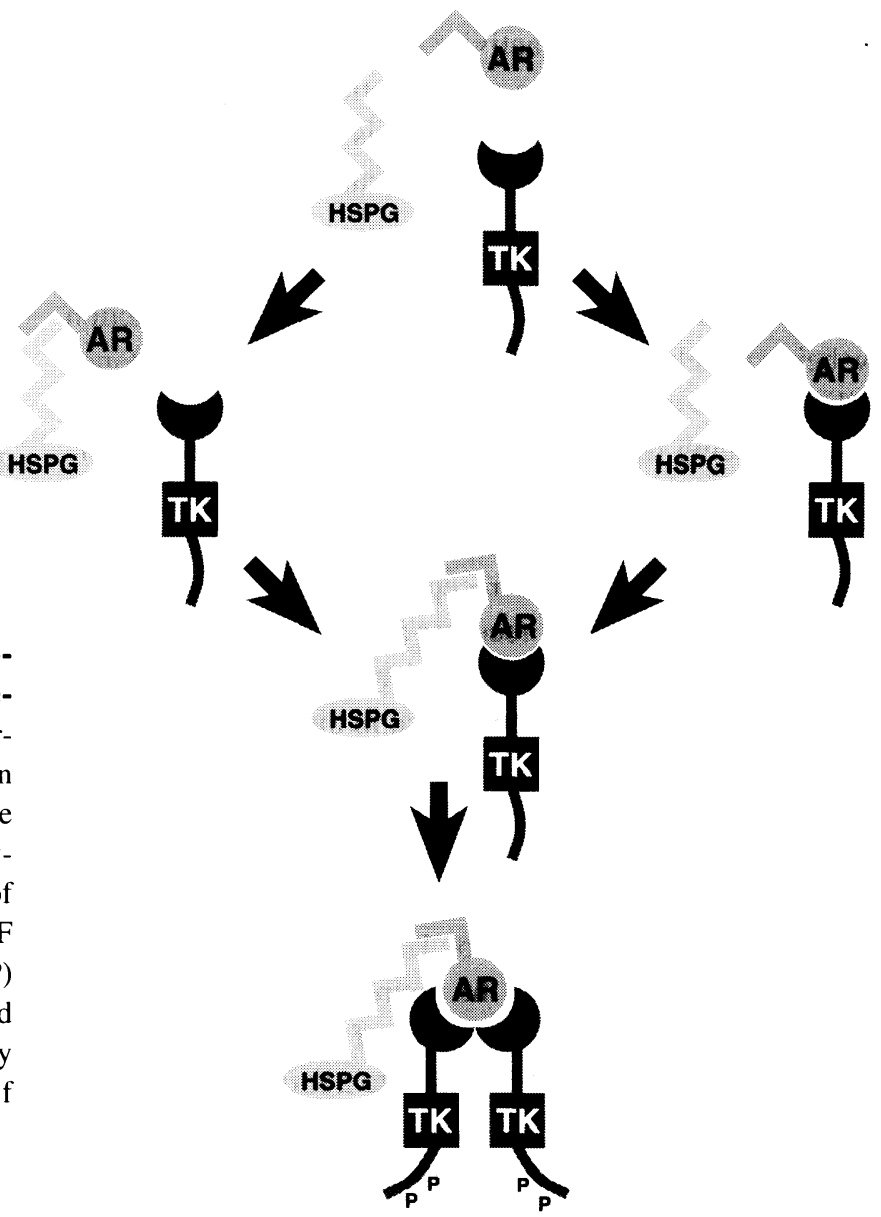

め込まれた HS 鎖なしでも、EGFレセプターと直接的に結合す るのかもしれない(40)。これらの情報のすべてより、アンフィ レグリンの作用の機構を提唱することができる(図 2)。アンフィ レグリンが球状の EGF 様ドメインとへパリン結合領域を含むN 末端の伸長配列を持つ構造として、描かれていることに、注目 せよ。アンフィレグリンは、最初にヘパラン硫酸プロテオグリ カン(HSPG)にでも EGF レセプターのリガンド結合領域にでも 結合することができる。まず始めに、アンフィレグリンが HS プ ロテオグリカンと結合する場合には、次に、HS 鎖はアンフィレ グリンをEGFレセプターに結合しやすいような空間配置で提示 する。一旦、アンフィレグリンがレセプターの単量体に提示さ れると、二量体化、自己リン酸化、EGFレセプターの活性化と シグナル伝達が順に起こる。これは、アンフィレグリンによる 作用発現のための機構だと考えられ、また、そう呼ばれてい る。アンフィレグリン分子が、まずEGFレセプターのリガンド 結合領域に結合したときには、プロテオグリカンの HS 鎖がア ンフィレグリンと結合することができるようになり、細胞表面 のリガンドとレセプター間の相互作用を安定化する。これが、 また、迅速にEGFレセプターの活性化とシグナル伝達を引き起 こす。この経路は、アンフィレグリンの作用の安定化機構であ ると呼ばれている。アンフィレグリンと HB-EGFの考えられう る違いは、HS プロテオグリカン欠損細胞で、HB-EGF のレセプ ターへの結合が可溶性のヘパリンにより回復するという点であ る(53)。HB-EGF の生物活性が回復するかどうかは示されていな 
(53). Whether HB-EGF bioactivity can be recovered has not been demonstrated. While the aforementioned discussion and mechanism focused on amphiregulin, this mechanism may be, at least partially, applicable to HB-EGF also.

\section{H. Conclusions}

The importance of proteoglycans in growth factor action is now being widely recognized. In addition to their importance in facilitating the ability of the growth factor to activate their signal-transducing receptor, proteoglycans provide an important regulatory function in the control of growth factor action. For example, for an FGF molecule to act at a specific site in vivo, both the appropriate FGF receptor and proteoglycan need to be expressed and the FGF, receptor and proteoglycan need to come together in the correct spatial orientation. Thus, this level of regulation is very likely to be critical in biological processes such as development whereby growth factor function can be controlled by the temporal and spatial expression of these three components. A variation on this basic theme was recently demonstrated in which the developmental regulation of neural response to the FGFs is controlled by HS proteoglycan structure (64). HS proteoglycan within the neuroepithelium of mouse embryos switchs between day 9 and 11 of development from a form which binds FGF-2 preferentially to a form which prefers to bind FGF-1.

The utilization of HS proteoglycan as a regulatory protein for the control of EGF receptor function in vivo appears to be very likely. Ligands for this receptor such as EGF and TGF$\alpha$ do not require HS proteoglycan to activate the receptor, in contrast to amphiregulin and HB-EGF which do. The necessity of HS proteoglycan for amphiregulin and HB-EGF action may provide another level of specificity and control for ligand-dependent signaling by this receptor. A number of important questions still remain in this regard. What is the essential HS proteoglycan? Is it limited to one proteoglycan or several? Can it function to facilitate growth factor activation of the EGF receptor as part of the basement membrane or extracellular matrix? What are the essential structures within the HS chains? From a more general standpoint, can specific inhibitors be designed and developed which can be used therapeutically to interfere with HS proteoglycan-dependent growth factor bioactivity? Further studies are clearly warranted in this relatively new and exciting area of biological research.
い。前述の議論と作用機構は、アンフィレグリンに焦点を当て たが、この機構が、少なくとも部分的には、HB-EGFにも適応 できるだろう。

\section{H. 結 論}

プロテオグリカンの成長因子の作用における重要性が、現 在、広く認識されつつある。シグナル伀達レセプターを活性化 する成長因子を賦活化するという重要性に加えて、プロテオグ リカンは、成長因子の作用を調節する、重要な制御機能を与え る。例えば、FGF 分子が、in vivoに拈いて、特定の部位で作用 するには、適切なFGFレセプターとプロテオグリカンが共に発 現している必要があり、FGFとレセプターとプロテオグリカン の三者が、正確な空間的配向をとることが必要である。それゆ え、このようなレべルでの制御は、発生のような生物学的過程 において決定的に重要であり、そこでは成長因子の機能は、こ れら三成分の時間的、空間的発現により調節されている。この 基本的な課題は、最近、FGFに対する神経反応の分化段階の制 御が、HS プロテオグリカンの構造によって調節されているこ とがわかり、違った局面を迎えている(64)。マウス胚の神経上 皮細胞中の HS プロテオグリカンは、9 から 11 日齢の間の分化 段階で、FGF-2 と優位に結合する型から、FGF-1 に結合する型 に変化する。

生体内で、EGFレセプターの機能を調節する調節蛋白質と して、in vivo でHS プロテオグリカンが利用されていることは、 非常にありそうなことである。EGF と TGF- $\alpha$ のようなリガン ドは、アンフィレグリンと HB-EGFとは对照的に、レセプター を活性化するのに、HS プロテオグリカンを必要としない。アン フィレグリンと HB-EGF の作用にHS プロテオグリカンが必要 であることによって、リガンドに依存したシグナル伝達にもう つのレベルの特異性を賦与し、調節を可能とする。この事に関 して、多くの重要な問題が、現在も残っている。必須の HS プ ロテオグリカンとは何であるか? ?れれ、1つのプロテオグリカ ンに限られるのか、それとも幾つかの種類が存在するのか? 基 底膜や細胞外マトリクスの一部として、EGFレセプターの成長 因子による活性化を可能にするように機能するのか? HS 鎖中の 必須の構造はなんであるか? 一般的な立場より、HS プロテオ グリカンに依存した成長因子の生理活性を阻害する特異的イン ヒビターが、デザインされ開発されて、治療に利用されるのだ ろうか?このような比較的新しく、刺激的な生物学の分野にお いて、さらなる研究が求められている。

神戸薬科大学・生化学教室

灘中 里美、菅原 一幸 共訳

\section{References}

1. Yanagishita, M., and Hascall, V.C. (1992) J. Biol. Chem. 267, 9451-9454

2. Ruoslahti, E. (1989) J. Biol. Chem. 264, 13369-13372

3. Ruoslahti, E., and Yamaguchi, Y. (1991) Cell 64, 867-869

4. Jackson, R.L., Busch, S.J., and Cardin, A.D. (1991) Physiol. Rev. 71, 481-539

5. Esko, J., Rostand, K.S., and Weinke, J.L. (1988) Science 241, 1092-1096 
6. Noonan, D., Fulle, A., Vallenta, P., Cai, S., Horigan, E., Sasaki, M., Yamada, Y., and Hassel, J. (1991) J. Biol. Chem. 266, 22939-22947

7. Bernfield, M., Kokenyesi, R., Kato, M., Hinkes, M.T., Spring, J., Gallo, R.L., and Lose, E.J. (1992) Annu. Rev. Cell Biol. 8, 365-393

8. David, G. (1993) FASEB J. 7, 1023-1030

9. Klagsbrun, M., and Baird, A. (1991) Cell 67, 229-231

10. Gitay-Goren, H., Soker, S., Vlodavsky, I., and Neufeld, G. (1992) J. Biol. Chem. 267, 6093-6098

11. Johnson, G.R., and Wong, L. (1994) J. Biol. Chem. 269, 27149-27154

12. Higashiyama, S., Abraham, J.A., and Klagsbrun, M. (1993) J. Cell Biol. 122, 933-940

13. Lopez-Casillas, F., Payne, H.M., Andres, J.L., and Massague, J. (1994) J. Cell Biol. 124, 557-568

14. Ullrich, A., and Schlessinger, J. (1990) Cell 61, 203-212

15. Schlessinger, J., and Ullrich, A. (1992) Neuron 9, 383-391

16. Heldin, C.-H. (1995) Cell 80, 213-223

17. Schlessinger, J. (1993) Trends Biochem. Sci. 18, 273-275

18. Davis, R.J. (1993) J. Biol. Chem. 268, 14553-14556

19. Davis, R.J. (1994) Trends Biochem. Sci. 19, 470-473

20. Marshall, C.J. (1995) Cell 80, 179-185

21. Darnell, J.E., Kerr, I.M., and Stark, G. R. (1994) Science 264, 1415-1421

22. Burgess, W.H., and Maciag, T. (1989) Annu. Rev. Biochem. 58, 575-606

23. Basilico, C., and Moscatelli, D. (1992) Adv. Cancer Res. 59, 115-165

24. Rapraeger, A.C., Krufka, A., and Olwin, B.B. (1991) Science 252, 1705-1708

25. Yayon, A., Klagsbrun, M., Esko, J.D., Leder, P., and Ornitz, D.M. (1991) Cell 64, 841-848

26. Roghani, M., Mansukhani, A., Dell'Era, P., Bellosta, P., Basilico, C., Rifkin, D.B., and Moscatelli, D. (1994) J. Biol. Chem. 269, 39763984

27. Kan, M., Wang, F., Xu, J., Crabb, J.W., Hou, J., and McKeehan, W.L. (1993) Science 259, 1918-1921

28. Turnbull, J., Fernig, D., Ke, Y., Wilkinson, M., and Gallagher, J. (1992) J. Biol. Chem. 267, 10337-10341

29. Habuchi, H., Suzuki, S., Saito, T., Tamura, T., Harada, T., Yoshida, K., and Kimata, K. (1992) Biochem. J. 285, 805-813

30. Maccarana, M., Casu, B., and Lindahl, U. (1993) J. Biol. Chem. 268, 23898-23905

31. Guimond, S., Maccarana, M., Olwin, B.B., Lindahl, U., and Rapraeger, A. C. (1993) J. Biol. Chem. 268, 23906-23914

32. Aviezer, D., Levy, E., Safran, M., Svahn, C., Buddeke, E., Shmidt, E., David, G., Vlodavsky, I., and Yayon, A. (1994) J. Biol. Chem. 269, $114-121$

33. Walker, A., Turnbull, J.E., and Gallagher, J.T. (1994) J. Biol. Chem. 269, 931-935

34. Aviezer, D., Hecht, D., Safran, M., Eisinger, M., David, G., and Yayon, A. (1994) Cell 79, 1005-1013

35. Spivak-Kroizman, T., Lemmon, M.A., Dikic, I., Ladbury, J.E., Pinchasi, D., Huang, J., Jaye, M., Crumley, G., Schlessinger, J., and Lax, I. (1994) Cell 79, 1015-1024

36. Carpenter, G., and Cohen, S. (1990) J. Biol. Chem. 265, 7709-7712

37. Hunter, T. and Cooper, J. A. (1981) Cell 24, 741-752

38. Derynck, R., Roberts, A.B., Winkler, M.E., Chen, E.Y., and Goeddel, D.V. (1984) Cell 38, 287-297

39. Massague, J. (1990) J. Biol. Chem. 265, 21393-21396

40. Shoyab, M., Plowman, G.D., McDonald, V.L., Bradley, J.G., and Todaro, G.J. (1989) Science 243, $1074-1076$

41. Plowman, G.D., Green, J.M., McDonald, V.L., Neubauer, M.G., Disteche, C.M., Todaro, G.J., and Shoyab, M. (1990) Mol. Cell. Biol. 10, 1969-1981

42. Cook, P.W., Mattox, P.A., Keeble, W.W., Pittelkow, M. R., Plowman, G.D., Shoyab, M., Adelman, J.P., and Shipley, G.D. (1991) Mol. Cell. Biol. 11, 2547-2557

43. Johnson, G.R., Saeki, T., Gordon, A.W., Shoyab, M., Salomon, D. S., and Stromberg, K. (1992) J. Cell Biol. 118, $741-751$

44. Johnson, G.R., Kannan, B., Shoyab, M., and Stromberg, K. (1993) J. Biol. Chem. 268, 2924-2931

45. Johnson, G.R., Prigent, S.A., Gullick, W.J., and Stromberg, K. (1993) J. Biol. Chem. 268, 18835-18843

46. Higashiyama, S., Abraham, J. A., Miller, J., Fiddles, J.C., and Klagsbrun, M. (1991) Science 251, 936-939

47. Besner, G.E., Whelton, D., Crissman-Combs, M.A., Steffen, C.L., Kim, G.Y., and Brigstock, D.R. (1992) Growth Factors 7, 289-296

48. Shing, Y., Christofori, G., Hanahan, D., Ono, Y., Sasada, R., Igarashi, K., and Folkman, J. (1993) Science 259, 1604-1607

49. Watanabe, T., Shintani, A., Nakata, M., Shing, Y., Folkman, J., Igarashi, K., and Sasada, R. (1994) J. Biol. Chem. 269, 9966-9973

50. Ono, M., Raab, G., Lau, K., Abraham, J.A., and Klagsbrun, M. (1994) J. Biol. Chem. 269, 31315-31321

51. Kimura, H., Fischer, W.H., and Schubert, D. (1990) Nature 348, 257-260

52. Ototani, N., Kikuchi, M., and Yoshizawa, Z. (1981) Carbohydr. Res. 88, 291-303

53. Aviezer, D., and Yayon, A. (1994) Proc. Natl. Acad. Sci. USA 91, 12173-12177

54. Bennett, K.L., Jackson, D.G., Simon, J.C., Tanczos, E., Peach, R., Modrell, B., Stamenkovic, I., Plowman, G., and Aruffo, A. (1995) J. Cell Biol. 128, 687-698

55. Thompson, S.A., Higashiyama, S., Wood, K., Pollitt, N. S., Damm, D., McEnroe, G., Garrick, B., Ashton, N., Lau, K., Hancock, N., Klagsbrun, M., and Abraham, J. A. (1994) J. Biol. Chem. 269, 2541-2549

56. Johnson, G. R., Saeki, T., Auersperg, N., Gordon, A.W., Shoyab, M., Salomon, D.S., and Stromberg, K. (1991) Biochem. Biophys. Res. Commun. 180, 481-488

57. Saeki, T., Stromberg, K., Qi, C., Gullick, W. J., Tahara, E., Normanno, N., Ciardiello, F., Kenney, N., Johnson, G.R., and Salomon, D.S. (1992) Cancer Res. 52, 3467-3473

58. Kitadai, Y., Yasui, W., Yokozaki, H., Kuniyasu, H., Ayhan, A., Haruma, K., Kajiyama, G., Johnson, G.R., and Tahara, E. (1993) Jpn. J. Cancer Res. 84, 879-884

59. Saeki, T., Salomon, D., Normanno, N., Johnson, G.R., Gullick, W.J., Mandai, K., Moriwaki, S., Takashima, S., Kuniyasu, M., Tahara, E., Kawami, H., Nishiyama, M., and Toge, T. (1994) Int. J. Oncol. 5, 215-223 
60. Qi, C.-F., Liscia, D.S., Normanno, N., Merlo, G., Johnson, G.R., Gullick, W.J., Ciardiello, F., Saeki, T., Brandt, R., Kim, N., Kenney, N., and Salomon, D.S. (1994) Br. J. Cancer 69, 903-910

61. Ebert, M., Yokoyama, M., Kobrin, M.S., Friess, H., Lopez, M.E., Buchler, M.W., Johnson, G. R., and Korc, M. (1994) Cancer Res. 54, 3959-3962

62. Margalit, H., Fischer, N., and Ben-Sasson, S.A. (1993) J. Biol. Chem. 268, 19228-19231

63. Lemmon, M.A. and Schlessinger, J. (1994) Trends Biochem. Sci. 19, 459-463

64. Nurcombe, V., Ford, M.D., Wildschut, J.A., and Bartlett, P.F. (1993) Science 260, 103-106

Received on April 10, 1995, accepted on April 21,1995 